\title{
Elintarviketuotannon vaikutus ilmastonmuutokseen ketjuvaiheittain
}

\author{
Juha-Matti Katajajuuri $^{1}$, Kirsi Usva ${ }^{2}$, Yrjö Virtanen ${ }^{3} \&$ Pasi Voutilainen $^{4}$ \\ ${ }^{1)}$ MTT Biotekniikka-ja elintarviketutkimus,31600Jokioinen, juha-matti.katajajuuri@mtt.fi \\ ${ }^{2)}$ MTT Biotekniikka- ja elintarviketutkimus,31600 Jokioinen, kirsi.usva@mtt.fi \\ ${ }^{3)}$ MTT Biotekniikka- ja elintarviketutkimus,31600 Jokioinen, yrjo.virtanen@mtt.fi \\ ${ }^{4)}$ MTT Biotekniikka-ja elintarviketutkimus, 31600 Jokioinen, pasi.voutilainen@mtt.fi
}

\section{Tiivistelmä}

Kasvava kulutus ja kansalaisten käyttämät tuotteet ovat ympäristöongelmien takana. Suomessa elintarvikekulutus aiheuttaa valtaosan kotitalouksien kulutuksen ympäristövaikutuksista. On tärkeää tuntea, mistä elintarvikeketjun osista ja prosesseista ympäristövaikutukset syntyvät, jotta niihin voidaan puuttua. Tässä artikkelissa tarkastellaan elinkaaren eri osien merkityksiä ympäristövaikutusten synnyssä käyttäen esimerkkinä muutamaa erityyppistä elintarviketta, nimittäin juustoa, kaurahiutaleita ja -puuroa, perunagratiinia ja virvoitusjuomia. Tarkastelu perustuu näistä tuotteista tehtyihin elinkaaritutkimuksiin, joissa ympäristökuormitustiedot hankittiin tuotantoketjujen todellisista prosesseista.

Eri elintarvikkeiden typpi- ja fosforikuormitus ja vesistöjen rehevöitymisvaikutus aiheutuvat valtaosin alkutuotannosta, erityisesti peltoviljelystä. Sitä vastoin elintarviketuotannon ilmastonmuutos- ja happamoitumisvaikutus aiheutuvat ketjun eri osista vaihdellen merkittävästi. Silloin kun kotona tapahtuva ruoan valmistus uunissa tai keittolevyllä oli mukana elintarvikkeen ketjussa, tästä aiheutuneet hiilidioksidipäästöt $\left(\mathrm{CO}_{2}\right)$ olivat koko ketjun ilmastonmuutosvaikutuksen suurimpia osatekijöitä.

Juuston tuotannon ilmastonmuutosvaikutuksesta suurin osuus (35\%) aiheutui lypsykarjan ruoansulatuksen metaanipäästöistä $\left(\mathrm{CH}_{4}\right)$. Maatalouden osuus juuston tuotannon ilmastonmuutosvaikutuksesta oli yhteensä $77 \%$, muina isoina tekijöinä mm. lannankäsittelyn typpioksiduulipäästöt $\left(\mathrm{N}_{2} \mathrm{O}\right)$. Puuron valmistus sähköliedellä oli suurin kaurahiutaleketjun ilmastonmuutosta aiheuttava tekijä ( $65 \%$ kokonaisvaikutuksesta). Jos kuluttaja kypsentäisi kaurapuuron mikroaaltouunissa, olisivat päästöt murto-osan siitä mitä ne ovat sähköliedellä lämmitettäessä. Virvoitusjuomien (olut) suurin ilmastonmuutosvaikutus aiheutui juomien jakelusta ja kaupasta. Myös juomapakkauksen valmistusketju saattaa olla merkittävä ilmastonmuutosvaikutuksen aiheuttaja pakkauksessa käytetyistä materiaaleista, niiden määristä ja kierrätysasteesta riippuen.

Juustokermaperunaketjussa suurin ilmastonmuutosta aiheuttava kuormituserä syntyi kaupassa (63 \%). Tämä johtui kylmäsäilytykseen käytettyjen pakastealtaiden käyttämän sähköenergian suhteellisesti suuresta määrästä myytyä tuoteyksikköä kohden. Ketjun aiheuttamaa ilmastonmuutosvaikutusta voitaisiinkin vähentää tehokkaimmin vähentämällä tuotteelle varattua pakasteallastilaa ja nopeuttamalla tuotteen kiertoa. Hiilidioksidipäästöjen osalta juustokermaperunaketjussa mielenkiintoista oli se, että maitopohjaisten kastikeraaka-aineiden tuotannossa syntyi enemmän päästöjä kuin perunan tuotannossa. Näin siitä huolimatta, että pääosa tuotteesta onkin perunaa.

Edellisten esimerkkien valossa näyttää siltä, että erityyppisten elintarvikkeiden ympäristövaikutukset, erityisesti ilmastonmuutosvaikutukset aiheutuvat elintarvikeketjun eri osista. Kuormittavin tekijä ei aina olekaan maatalous tai elintarviketeollisuus. Tutkittujen elintarvikkeiden välillä eroja ilmastonmuutosvaikutuksessa aiheuttivat $\mathrm{mm}$. energialähteiden valinta, materiaali- ja energiatehokkuus sekä saannot ketjun eri osissa, kylmäaltaiden kiertonopeudet kaupassa, ruoan valmistustavat sekä erityyppisten raakaaineiden kuten eläin- ja kasviperäisten raaka-aineiden suhde lopullisessa elintarvikkeessa.

Asiasanat: elinkaarianalyysi, LCA, ympäristövaikutukset, ilmastonmuutos, tuotantoketju, elintarvike, ruoka 


\title{
Tausta
}

Kasvava kulutus ja kansalaisten käyttämät tuotteet ovat välittömästi tai välillisesti useimpien teollisuusmaiden ympäristöongelmien takana. Elintarvikekulutus aiheuttaa ison osan kotitalouksien kulutuksen ympäristövaikutuksista. Ympäristöongelmien lähestyminen tuotenäkökulmasta tarjoaa uusia mahdollisuuksia. Tuotelähtöinen ympäristöpolitiikka ja -hallinta perustuvat elinkaariajatteluun. Se siirtää huomion valmistusvaiheesta itse tuotteeseen ja koko sen tuotantoketjuun, sekä ketjun loppupäässä niihin ihmisten tarpeisiin, joita tuotteen käyttö tyydyttää. Nykyaikaisessa liiketoiminnassa tuotelähtöinen kestävyys- ja ympäristöhallinta ovat osa kilpailukyvylle tärkeän liiketoimintaketjun hallintaa.

Tämän artikkelin taustalla olleiden elinkaaritutkimusten lähtökohtana oli kasvava tarve alkaa tuottamaan luotettavia ympäristövaikutustietoja elintarvikesektorin tuotteista ja kehittää elintarvikkeita ja niiden tuotantoprosesseja ympäristöä vähemmän rasittaviksi. Kotitalouksien kulutuksen ympäristövaikutukset tulisi siis saada näkyviksi ja kuluttajille tunnetuiksi, mikä mahdollistaisi niiden käytön ostovalinnan tukena. Siten kuluttajat voisivat elintarvikkeiden päivittäiskäyttöään muuttamalla pienentää ympäristövaikutuksia, sillä edellytyksellä, että tietoa eri elintarvikkeiden kulutuksen merkityksistä kokonaisympäristövaikutuksille olisi olemassa heidän valintapäätöksiään tukemaan.

\begin{abstract}
Aineisto ja menetelmät
Artikkelissa esitettävät tulokset perustuvat pääosin vuonna 2003 julkaistuun (Katajajuuri ym. 2003, Voutilainen ym. 2003a, Voutilainen 2003b) ja vuonna 2005 päivitettyyn Foodchain-tutkimuksen tuloksiin. Foodchain-tutkimuksessa selvitettiin Emmental juuston, Elovena kaurahiutaleiden, Kesäpöytä Juustokermaperunoiden ja Pirkka perunajauhon ympäristövaikutukset. Virvoitusjuomien (oluen) ympäristövaikutukset pohjautuvat meneillään olevan "Mallasohra -toimintoverkon kestävyyden parantamisen työkalut" hankkeeseen (Virtanen ym. 2006) ja "Suomalaisten juomapakkausjärjestelmien ympäristövaikutusten arviointi 2000"-hankkeeseen (Virtanen ym. 2002).

Tutkimuksissa otettiin huomioon tarkasteltujen kuluttajatuotteiden olennaisten tuote- ja jakelujärjestelmien eri vaiheet aina maatilatuotannon panostuotannosta ja sen raaka-aineista kaupan hyllyyn ja valmiiksi ruoaksi asti. Kuluttajan ostosmatka ei arvioon sisältynyt. Tutkimusten tuloksien perusteella ei voida suoraan vertailla esimerkiksi eläinperäistä ja kasvisruokaa, sillä tutkimuksessa käytetyt toiminnalliset yksiköt olivat tuotteiden massoja eivätkä siten ole toiminnallisesti yhteismitallisia.

Tutkimuksissa sovellettu ympäristövaikutusten arviointimenetelmä oli perinteisen, standardoidun elinkaariarvioinnin (Life Cycle Assessment, LCA, ISO 14040 -sarja) sovellus, joka on kiinteämmin toimintoverkkoon integroitu kuin perinteiset, ulkopuolisesti toteutetut elinkaariarvioinnit. Menetelmä nojaa teollisen ekologian ideologiaanı, elinkaariarvioinnin tekniikkaan sekä toimintoverkkojen ja innovaatioiden hallinnan toimintatapoihin. Käytännön lähtökohtana on tällöin, että ympäristökuormitustiedot hankittiin tuotantoketjujen todellisista prosesseista. Siksi tulokset ovat tuotantoketju- ja tapauskohtaisia. Niiden perusteella ei tulisi suoraan tehdä johtopäätöksiä muissa yhteyksissä.
\end{abstract}

\section{Tulokset ja tulosten tarkastelu}

Seuraavassa tuloksia esitetään case-kohtaisesti kolmen elintarvikkeen osalta.

\section{Emmental Juusto}

Kaikissa tutkituissa ympäristövaikutusluokissa suurin osa juuston tuotannon ympäristövaikutuksista syntyy alkutuotannosta. Rehevöitymiseen vaikuttaa eniten peltoviljely ja happamoitumispotentiaaliin ammoniakin haihdunta lannasta ja virtsasta. Eläinten ruuansulatuksesta vapautuvan metaani oli suurin ilmastonmuutosta aiheuttava tekijä. Eläinten ruuansulatuksessa vapautuvan metaanin määrään on vaikea vaikuttaa. Maitotilan metaanipäästöjen jälkeen suhteellisesti suurimmat kasvihuonekaasupäästöt aiheutuivat rehun tuotannosta maitotiloilla ja väkirehujen raaka-aineiden tuotantotiloilla. Tähän vaikuttivat lannoitteista ja lannasta vapautuvat typpioksiduulipäästöt sekä hiilidioksidipäästöt, joita aiheutui viljan kuivaamisesta, työkoneista ja kalkituksesta. Energian kulutuksen kautta kaikissa vaiheissa syntyy hiilidioksidia, joka on yleisin ilmastonmuutoskaasu, joskaan juuston tuotannon kannalta se ollutkaan suhteellisesti niin suuri kuin metaani ja typpioksiduuli, vaan hiilidioksidipäästöjen osuus oli $29 \%$ ilmastonmuutosvaikutuksesta. 


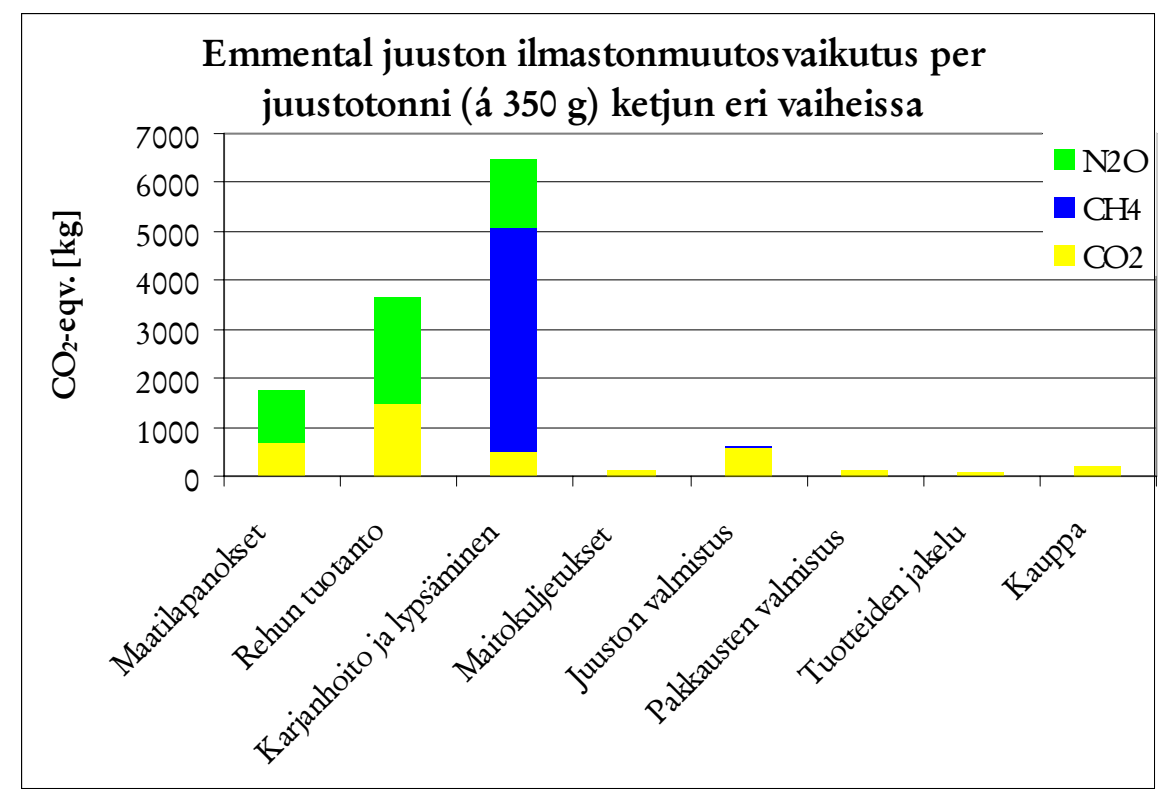

Kuva 1. Emmental juuston ilmastonmuutosvaikutus $1000 \mathrm{~kg}$ juustoa kohden tuotantoketjun eri vaiheissa.

\section{Kaurahiutaleet ja-puuro}

Puuron valmistus sähköliedellä aiheutti moninkertaiset hiilidioksidipäästöt suhteessa kaurahiutaleiden tuotantoketjuun. Puuron valmistus sähköliedellä oli suurin tuotejärjestelmän ilmaston lämpenemistä aiheuttava tekijä. Valmistamalla puuro mikroaaltouunissa, useat ilmapäästöt ja niistä aiheutuvat ympäristövaikutukset olivat huomattavasti pienemmät kuin sähköliedellä valmistettaessa. Kaurahiutaleiden tuotantovaiheen ympäristökuormitukset ja -vaikutukset aiheutuivat pääosin alkutuotannosta. Ilmastonmuutosvaikutukseen hiutaleketjusta vaikuttivat eniten lannoitteista denitrifioituva typpioksiduuli sekä hiilidioksidipäästöt työkoneiden käytöstä, kauran kuivauksesta ja kalkituksesta.

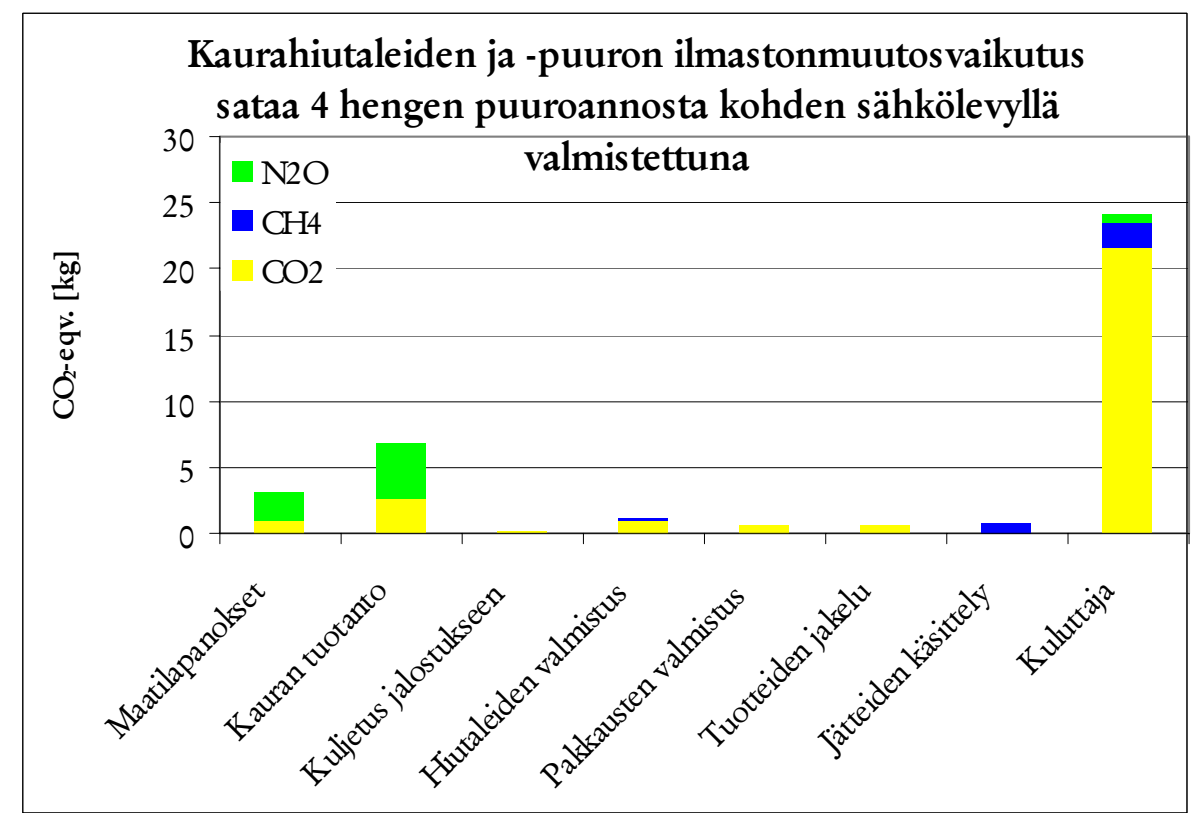

Kuva 2. Kaurahiutaleiden ja -puuron ilmastonmuutosvaikutus sataa neljän hengen puuroannosta kohden sähkölevyllä valmistettuna tuotantoketjun eri vaiheissa. 


\section{Juustokermaperunagratiini}

Juustokermaperunoiden tuotejärjestelmän suurimmaksi yksittäiseksi ilmaston lämpenemiseen vaikuttavaksi tekijäksi todettiin tuotteen säilyttäminen kaupan pakastinaltaassa. Kuluttajan ruoanvalmistus uunissa todettiin seuraavaksi suurimmaksi tekijäksi ketjussa. Suurin yksittäinen tekijä tuotantoketjun osalta oli gratinoinnin kryogeenisen prosessin jäähdytystypen valmistuksella. Raaka-aineiden osalta kastikkeen osuus ilmastonmuutosvaikutukseen oli suurempi kuin perunan tuotannon osuus. Rehevöitymiseen eniten vaikuttava tekijä oli kastikeraaka-aineiden tuotanto.

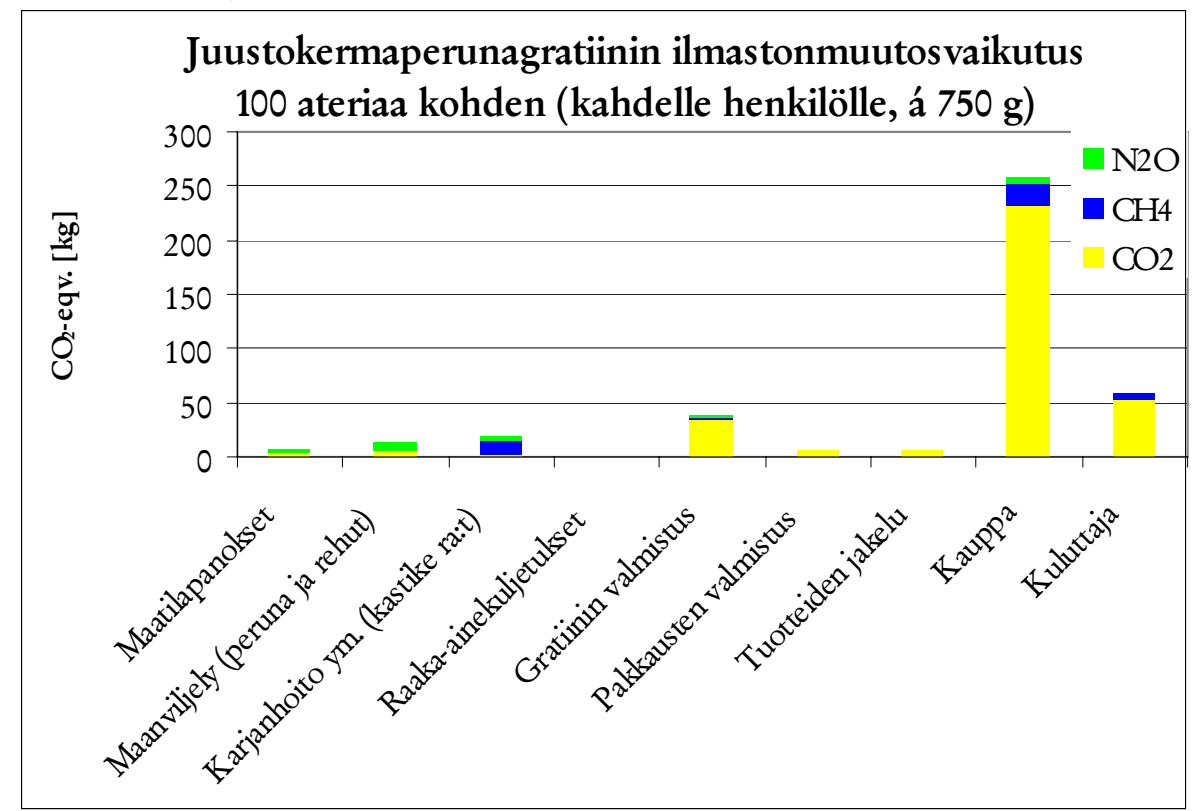

Kuva 3. Perunagratiinin ilmastonmuutosvaikutus 100 ateriaa kohden (2 hengelle) tuotantoketjun eri vaiheissa.

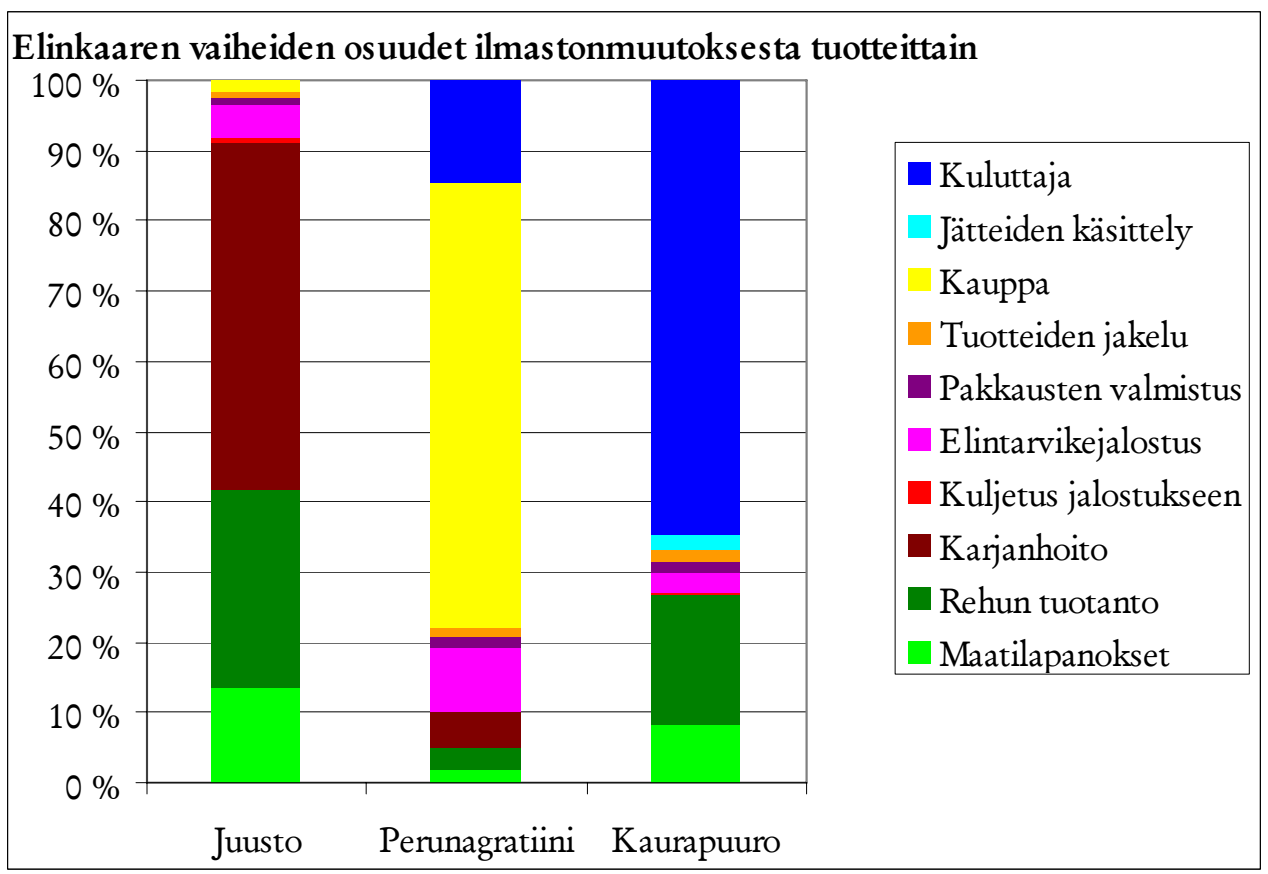

Kuva 4. Ilmastonmuutostulokset kolmen elintarvikkeen osalta tuotantoketjun eri osien suhteellisina osuuksina. 


\section{Johtopäätökset}

Elintarvikkeiden ympäristövaikutusten tuntemus ja hallinta ovat keskeisiä kestävän kehityksen haasteita. Elinkaariarviointi on menetelmä, jota käyttäen näihin haasteisiin vastaaminen helpottuu. Se kattaa koko arvoketjun ja mahdollistaa ympäristölaadun parantamiseen käytettävissä olevien resurssien kohdentamisen arvoketjun potentiaalisimpiin kohteisiin.

Ensikäden hyöty kuvatuista elinkaarihankkeista oli ympäristötiedon hallinnan ja sen vaatiman yhteistyön kehittyminen tuotejärjestelmän toimijoiden keskuudessa. Useat osallistuneet yritykset ovat hankkeen aikana tai jälkeenpäin päättäneet lisätä prosessiensa mittaamista, jotta prosessien ja tuotteiden arviointiin ja kehittämiseen olisi jatkossa käytettävissä ajanmukaista ja entistä luotettavampaa tietoa.

Hankkeissa tuotetut ympäristövaikutustiedot ja ketjusta tehdyt havainnot olivat toimijoille monin tavoin hyödyllisiä. Koska hankkeen olivat luonteeltaan vasta ensimmäisiä Suomessa, on kuluttajien valintojen tueksi vielä kovin vähän ympäristövaikutustietoa saatavilla. Tutkimattomista tuoteryhmistä on käynnistetty case-tutkimukset sittemmin broilerinlihasta ja kasvihuonekurkusta. Tehtyjen ja meneillään olevien ketjukohtaisten LCA-tutkimuksien tuloksien perusteella ei voida vielä vertailla esimerkiksi eläinperäistä ja kasvisruokaa. Näissä kertyneen pohjatietämyksen varaan MTT on rakentamassa uutta hanketta yhteistyössä Suomen ympäristökeskuksen, Kuluttajatutkimuskeskuksen ja Oulun yliopiston kanssa. Hankkeen tavoitteena olisi tutkia, miten elintarvikekulutuksen kokonaisympäristövaikutukset jakaantuvat eri tuoteryhmien kesken.

Tuotteita koskeva ympäristövaikutustieto ei vielä yksinään riitä kuluttajien ekologisesti kestävien valintojen tueksi. Kuluttajien näkökulmasta jonkinlainen mittari olisi tarpeen tuotteiden ympäristövaikutustietojen havainnollistamiseksi ja ymmärtämiseksi. Näistä lähtökohdista Suomen ympäristökeskus, MTT, Kuluttajatutkimuskeskus ja Riista- ja kalatalouden tutkimuskeskus ovatkin kehittämässä ns. mittatikku-menetelmää (ks. esim. Nissinen et al. 2005), uudenlaista LCA-tulosten esittämistapaa.

Usein on esitetty väitteitä siitä, että noin 80-90 prosenttia elintarviketuotannon ympäristövaikutuksista aiheutuu maataloudesta. Hankkeiden tutkimustulosten perusteella eri tuotteiden ympäristövaikutukset ja niiden jakaumat vaihtelevat vaikutusluokittain kuitenkin merkittävästi tuotteiden välillä. Tutkimattomien tuoteryhmien osalta ei siis voida mielekkäästi ennustaa mikä ketjun osa aiheuttaa suurimmat ympäristövaikutukset eikä ennen kaikkea, missä olisivat suurimmat parannusmahdollisuudet. Artikkelin keskeisenä kohteena ollut ilmastonmuutosvaikutus aiheutui eri ketjuista täysin erilaisista ketjuvaiheista. Kuormittavin tekijä ei aina olekaan maatalous, vaan se voi olla esimerkiksi tuotteiden valtakunnallinen jakelu ja kauppa tai sitten ruoanvalmistus kotitaloudessa. Myös maatalouden ja elintarviketeollisuuden suhteelliset osuudet ilmastonmuutosvaikutuksesta vaihtelivat. Tutkittujen elintarvikkeiden välillä eroja ilmastonmuutosvaikutuksessa aiheuttivat $\mathrm{mm}$. energialähteiden valinta, materiaali- ja energiatehokkuus sekä saannot ketjun eri osissa, kylmäaltaiden kiertonopeudet kaupassa, ruoan valmistustavat sekä erityyppisten raaka-aineiden kuten eläin- ja kasviperäisten raaka-aineiden suhde lopullisessa elintarvikkeessa.

Tulokset osoittivat havainnollisesti myös sen, että tarkastelemalla vain tiettyjä päästöjä, kuten hiilidioksidia, saatetaan tuotejärjestelmän ilmastonmuutosvaikutuksesta saada kokonaisuuden kannalta riittämätön kuva, koska voimakkaita kasvihuonekaasuja, metaania ja typpioksiduulia, aiheutuu useista elintarvikeketjun osista suhteellisen suuria määriä. Esimerkiksi metaanipäästöjä havaittiin syntyvän suhteellisen paljon muuhun ketjuun nähden lypsykarjasta, lannoituksesta ja kaatopaikoilta riippuen elintarvikkeen raaka-aineesta ja pakkausmateriaalista. Näin ollen esimerkiksi energiankäyttö ympäristövaikutusten mittarina ei kata läheskään kaikkia elintarvikkeiden olennaisia ympäristövaikutuksia, ja saattaisi monessa kohtaa johtaa päätöksentekijöitä harhaan.

\section{Kiitokset}

Suurkiitos tutkimusten tekemisen ja valmistumisen mahdollistaneelle laajalle joukolle kotimaisia alan tutkijoita sekä aktiivisesti hankkeiden toteuttamiseen ja rahoittamiseen osallistuneita yrityksiä: Altia, Hartwall, Kemira GrowHow, Lännen Tehtaat, RavintoRaisio, Ruokakesko, Sinebrychoff, Suomen Rehu, Valio \& Viking Malt. Lisäksi kiitos hankkeiden julkisille rahoittajatahoille Ympäristöklusterin tutkimusohjelmalle, Maa- ja metsätalousministeriölle ja sen laatustrategia -ryhmälle ja Tekesille. 


\section{Kirjallisuus}

Katajajuuri, J.-M., Voutilainen, P., Tuhkanen, H.-R., Honkasalo, N. Elovena-kaurahiutaleiden ympäristövaikutukset. Maa- ja elintarviketalous (2003):33, 47 s. + 1 liite http://www.mtt.fi/met/pdf/met33.pdf, Verkkojulkaisu päivitetty 15.10.2003.

Nissinen, A., Heiskanen, E., Grönroos, J., Honkanen, A., Katajajuuri, J.-M., Kettunen, J., Kurppa, S., Mäkinen, T., Seppälä, J., Silvenius, F., Timonen, P., Virtanen, Y., Voutilainen, P. 2005. Developing LCA-based benchmarks for sustainable consumption - for and with users. $10^{\text {th }}$ European Roundtable on Sustainable Consumption and Production. October 5-7, 2005, Antwerp, Belgium. 21 p.

http://www.vito.be/erscp2005/documents/papers/PAPER145.PDF.

Voutilainen, P., Katajajuuri, J.-M., Tuhkanen, H.-R., Honkasalo, N. 2003a. Kesäpöytä Juustokermaperunoiden ja Pirkka-perunajauhon ympäristövaikutukset. Maa- ja elintarviketalous (2003):34, 54 s

http://www.mtt.fi/met/pdf/met34.pdf, Verkkojulkaisu päivitetty 15.10.2003

Voutilainen, P., Tuhkanen, H.-R., Katajajuuri, J.-M., Nousiainen, J. 2003b. Emmental Sinileima -juuston tuotantoketjun ympäristövaikutukset ja parannusmahdollisuudet. Maa- ja elintarviketalous (2003):35, 91 s. + 2 liitettä http://www.mtt.fi/met/pdf/met35.pdf, Verkkojulkaisu päivitetty 15.10.2003

Virtanen, Y., Ojaniemi, U., Poikkimäki, S., Katajajuuri, J-M. 2002. Life cycle assessment of potential environmental impacts of Finnish beverage packaging systems. $0.31-0.51$ glass bottles, aluminium cans and PET bottles for beer, cider and carbonated soft drinks. Summary Report. PTR report NO. 51a. 101 p. ISBN 951-8988-32-3.

Virtanen, Y., Usva, K. \& Katajajuuri, J.-M. 2006. Mallasohra -toimintoverkon kestävyyden parantamisen työkalut (MOKE). Mallasohra -toimintoverkon ympäristövaikutukset. LUONNOS. 